\title{
TRANSMISSIBILITY OF Fusarium oxysporum f. sp. Vasinfectum INOCULATED IN COTTONSEEDS
}

\author{
PINHEIRO, Rodrigo Porfírio ${ }^{1}$ \\ ARAÚJO, Dejânia Vieiraª \\ ASCARI, João Paulo ${ }^{3}$ \\ ALVES, Marcelo de Carvalho ${ }^{4}$ \\ MAINARDI, Janile Tamiozzo $0^{5}$
}

\begin{abstract}
SUMMARY: The objective of this study was to evaluate the transmissibility of Fusarium oxysporum f.sp. vasinfectum by inoculated cottonseeds. The cottonseeds were inoculated using the water restriction technique, at different times of exposure. A completely randomized design was used in the laboratory and a randomized design with blocks was used in the field experiment, with a 2x5 factorial arrangement with two cultivars (FMT 701 and Delta Opal) and five times of exposure of the pathogen in seeds $(0 \mathrm{~h}, 24 \mathrm{~h}, 48 \mathrm{~h}, 72 \mathrm{~h}$ and $96 \mathrm{~h})$. There was a reduction in the percentage of germination with the increase of the infection of the seeds when in greater time of contact with the fungus. Delta Opal cultivar presented minor disease index and major pathogen incidence when compared to FMT 701 cultivar. The rates of infection and transmission of the seed pathogen were effective and directly proportional to the inoculum potential in the seeds, with rates of $95 \%$ and $1.2 \%$, respectively.
\end{abstract}

Keywords: Gossypium hirsutum. Seed pathology. Inoculation.

\section{TRANSMISSIBILIDADE DE Fusarium oxysporum f. sp. vasinfectum INOCULADO EM SEMENTES DE ALGODÃO}

\begin{abstract}
RESUMO: O objetivo deste estudo foi avaliar a transmissibilidade de Fusarium oxysporum f.sp. vasinfectum por sementes de algodão inoculadas. As sementes foram inoculadas utilizando a técnica de restrição hídrica, em momentos diferentes. Um delineamento inteiramente casualizado foi utilizado no laboratório e um desenho randomizado com blocos foi utilizado no experimento de campo, com arranjo fatorial $2 \times 5$, com duas cultivares (FMT 701 e Delta Opal) e cinco tempos de exposição do patógeno em sementes (0 h, 24 h, 48 h, 72 h e 96 h). Houve uma redução na percentagem de germinação com o aumento da infecção das sementes quando em maior tempo de contato com o fungo. Cultivar Delta Opal apresentou índice de doença menor e maior incidência do patógeno, quando comparado com FMT 701. As taxas de infecção e transmissão do patógeno via sementes foram eficazes e diretamente proporcional ao potencial de inóculo nas sementes, com taxas de $95 \%$ e 1,2\%, respectivamente.
\end{abstract}

Palavras-chave: Gossypium hirsutum. Patologia de sementes. Inoculação.

\section{INTRODUCTION}

Integration of a high technological level in the cotton fields and breeding of cultivars resulted in the consequent spread of many pathogens. Most pathogens transmitted by seeds may be linked to the

\footnotetext{
${ }^{1}$ Engenheiro Agrônomo. Universidade do Estado de Mato Grosso

${ }^{2}$ Professora de Fitopatologia da Universidade do Estado de Mato Grosso, Tangará da Serra, MT, Brasil.

${ }^{3}$ Engenheiro Agrônomo, Mestre em Ambiente e Sistema de Produção Agrícola, Doutorando em Fitopatologia. Universidade do Estado de Mato Grosso

${ }^{4}$ Professor da Faculdade de Agronomia e Medicina Veterinária, Departamento de Solos e Engenharia Rural, Universidade Federal de Mato Grosso, Cuiabá, MT, Brasil

${ }^{5}$ Mestre em Produção Vegetal, Agrodinâmica Pesquisa e Consultoria Agropecuária, Tangará da Serra, MT, Brasil.
} 
plants in different ways, contaminating the surface, or colonizing the internal tissues (TEIXEIRA, 1997). In this context, etiology of fungal pathogens associated with the crop, whose relative importance depends on climatic conditions, has been reported in the State of Mato Grosso, as is the case of Fusarium wilt whose etiologic agent is Fusarium oxysporum Schlechtend., Fr f. sp. vasinfectum (Atk.) W. C. Snyder e Hans.

Symptoms of Fusarium wilt can occur at any stage of cotton development. The seedlings, when infected, die easily and, in some cases, symptoms can be confused with damping (damping off) caused by other pathogens. The symptoms of senescence and browning of vessels may be related to the production of ethylene and oxidation of phenols (DAVIS et al., 2006). In addition, other factors such as the process of infection and colonization of roots by nematodes (COLYER, 2001) and conditions of fertility and soil pH favors the occurrence of the disease. Another important feature concerns the survivability of the pathogen. Once established in the area, it was difficult to eliminate the pathogen from the soil. Smith \& Snyder (1975) reported the presence of resistance structures of $F$. oxysporum $f$. sp. vasinfectum in soil for up to 12 years in the absence of crop. What further strengthens the need to prevent the entry of the pathogen in cultivated areas is via seeds or other means.

The most efficient way to prevent the occurrence of the disease is the use of health seeds without the pathogen and with fungicides. Other alternatives for the management of the disease are crop rotation and use of resistant cultivars (SUASSUNA e COUTINHO, 2007; MACHADO et al., 2009). The transmission of the pathogen by seed is not well understood, although there were reports in several regions of the world, with conflicting results regarding the percentage of transmission from plant to seed (KULKARNI, 1934; VEIGA, 1935; PERRY, 1962; BENNETT et al., 2008).

It is necessary to obtain seeds with different levels of inoculum to assist the studies of detection and transmission of F. oxysporum f. sp. vasinfectum. Due to the difficulties of having cottonseeds infected by this pathogen inoculation methods became necessary (TANAKA et al., 1989; TANAKA;MENTEN, 1991; MACHADO et al., 2004; MACHADO et al., 2007).

Thus, the objective of this study was to evaluate the transmissibility of Fusarium oxysporum f.sp. vasinfectum by inoculated cotton seeds.

\section{MATERIAL AND METHOD}

The tests were conducted at the Laboratory of Plant Pathology and in the field at the State University of Mato Grosso (UNEMAT), Tangara da Serra city, located at coordinates of latitude $14^{\circ} 39^{\prime}$ $07^{\prime \prime} \mathrm{N}$, longitude $57^{\circ} 26^{\prime} 02^{\prime \prime} \mathrm{W}$ and altitude of $320 \mathrm{~m}$.

The experiment was conducted with two cultivars of cotton, FMT 701 and Delta Opal. The germination test was carried out on towel paper, in which 25 seeds were distributed per roll, totaling 200 seeds of each cultivar and conducted in accordance with the Rules for Seed Analysis (BRAZIL, 2009). For the sanity test, the method of incubation in substrate (Blotter Test) was adopted. The substrate was moistened with sterile distilled water (NEERGAARD, 1979) plus 2,4-D (diclorofenoxiacetic acid) at a concentration of $10 \mathrm{ppm}$ (LANGERAK;MACHADO, 1993). The results of germination and seed health were converted to percentage of normal seedlings and incidence of fungi in seeds, respectively.

\section{Seed inoculation}

Inoculation of seeds was proceeded with an isolate of $F$. oxysporum f. sp. vasinfectum, obtained from cotton plants collected in the Mato Grosso State and characterized according to morphological and molecular characteristics (NELSON et al., 1981; ARAÚJO, 2008). The isolate was transferred to Petri 
dishes of nine inches diameter, containing potato dextrose agar medium (PDA) and incubated at controlled chamber with temperature of $25^{\circ} \mathrm{C} \pm 2^{\circ} \mathrm{C}$ and photoperiod of $12 \mathrm{~h}$, per seven days. After this period, plates with vigorous fungi colonies were washed and one milliliter of spore suspension was transferred to plastic trays, sterilized in formalin for $24 \mathrm{~h}$, containing PDA medium plus mannitol. The water potential of the medium was adjusted to $-1 \mathrm{MPa}$ according to the results obtained in the software MPPS (MICHEL; RADCLIFFE, 1995). The inoculum was distributed evenly over the substrate with Drigalski loop. After this step, the trays were incubated in a $25^{\circ} \mathrm{C} \pm 2{ }^{\circ} \mathrm{C}$ chamber and photoperiod of $12 \mathrm{~h}$.

Seeds of two cultivars were sterilized separately with sodium hypochlorite $(\mathrm{NaClO}) 2 \%$ for one minute and then air dried for $24 \mathrm{~h}$ on autoclaved newspapers. After this process, the seeds were placed on culture medium with the fungus, agitated and incubated in controlled chambers at $25^{\circ} \mathrm{C} \pm 2{ }^{\circ} \mathrm{C}$ and photoperiod of $12 \mathrm{~h}$. Seeds stayed with the times of exposure to the fungus of $24 \mathrm{~h}, 48 \mathrm{~h}, 72 \mathrm{~h}$ and $96 \mathrm{~h}$, for both cultivars. The zero time was composed of seeds of both cultivars, disinfected and without inoculation. Completing each exposure time, the seeds were removed from incubation and placed on paper, which remained at room temperature for $24 \mathrm{~h}$. After drying, seeds were submitted to germination test and the rest was packed in paper bags and stored at room temperature to be brought to the field.

\section{Seed health and germination test}

After inoculation, seeds were tested by seed health analysis (NEERGAARD, 1979). First of all, seeds were underwent sterilization with sodium hypochlorite $2 \%$ for a minute and dried at temperature of $12 \mathrm{~h}$. The disinfection of seeds at this stage was performed in order to determine the percentage of seeds infected with the pathogen. Then, the health test with modification was prepared. Liquid and semiselective medium containing PCNB (Pentachloronitrobenzol) plus 2,4-D were added to the substrate paper, in order to highlight the purple color presented by the structures of the fungus (SOUSA et al., 2008). After seven days of incubation at temperature of $23^{\circ} \mathrm{C} \pm 2{ }^{\circ} \mathrm{C}$ and a photoperiod of $12 \mathrm{~h}$, seeds were examined under the stereoscope and the incidence of $F$. oxysporum f. sp. vasinfectum was estimated in percentage of occurrence of the pathogen by treatment. Germination test, was performed according to the rules for seed analysis (BRAZIL, 2009) and the results were given in percentage of normal seedlings, as previously reported.

Germination and seed health tests were arranged in a completely randomized with a factorial design of 2x5, it was two cultivars (FMT 701 and Delta Opal) and five exposure times of seeds to the pathogen (0h, 24h, 48h, 72h and 96h).

\section{Influence of the pathogen in reproductive and vegetative features}

The field experiment consisted of ten treatments with four replications, totaling 40 plots. The plots consisted of four rows with five meters long. The spacing used between rows was $0.9 \mathrm{~m}$ and 11 seeds sown per meter. Inoculated seeds were sown only in the useful area of the plots. Useful sampled area consisted of the two central rows separated by a meter between treatments and two meters between blocks. The experiment was arranged in randomized blocks with a factorial design of $2 \times 5$, it was two cultivars (FMT 701 and Delta Opal) and five times of exposure of the seeds to the pathogen (0h, 24h, 48h, 72h and 96h).

Initial and final stands were evaluated at 10 and 30 days after seedling emergence. Plants of the two central lines were counted and transformed in percentage of seedlings with cotyledons above the ground.

At 120 days after emergence (DAE) it was evaluated the height of plants from the measurement of 20 plants per plot, previously marked. Plants were measured from ground level to the apex and the result 
expressed in meters. Number of perfect and malformed cotton bolls were evaluated in the same plants. Cotton bolls with green color were considered perfect and with dark coloration or dried as malformed bolls.

The useful area of plots was harvested manually to determine the yield, ignoring $0.5 \mathrm{~m}$ of the extremity of each plot. After harvesting, the production per plot was evaluated by weighing the cottonseeds and the data was extrapolated to kg ha-1. Meteorological data for temperature, humidity and rainfall were measured daily from the meteorological station located at the experimental area.

\section{Transmissibility of the pathogen by inoculated seeds}

Occurrence of symptoms and signals of Fusarium wilt were evaluated in the each plot along the crop cycle. Disease transmission from seed to plant was determined based on the symptoms of the disease at the final of the cropping season after harvest, where the 20 marked plants in each plot were removed and sent to the laboratory of Plant Pathology for analysis of beams vascular.

The pathogen transmission seed to plant and plant to produced seed was determined based on the incidence and severity (ID) of disease and rates of infection (TI) and transmission (TT).

Disease incidence was determined based on number of stems symptomatic of the total assessed, or rods $30 \mathrm{~cm}$ long cut longitudinally considering 20 plants per plot. Data were converted into percentage of plants with vascular browning.

To assess the severity of the disease, the same stems of 20 plants per plot were evaluated based on scores varying from 0 to 3 according to the modified scale of Cia et al. (2008). Grade 0 equaled to no symptoms stem; grade 1 to mild vascular browning at the base or through the pole; grade 2 to severe vascular browning until the middle of the pole and grade 3 to severe vascular browning throughout the rod. Data were weighted by applying the formula described by McKinney (1923): ID (\%) $=[\Sigma(\mathrm{fv}) / \mathrm{nx}]$ * 100 , where ID is the disease index, $\mathrm{f}$ is the number of plants with particular note, $\mathrm{v}$ is the note observed, $\mathrm{n}$ is the total number of plants evaluated, $\mathrm{x}$ is the maximum degree of the severity scale at the plot.

The rates of infection (IR) and transmission (TR) of F. oxysporum $\mathrm{f}$. sp. vasinfectum to the plant and to the produced seeds were determined using a methodology adapted from Teixeira e Machado (2003).

To determine the IR, plant fragments of three centimeters of the stem of the 20 plants were sterilized with sodium hypochlorite $2 \%$ for one minute, rinsed three times in sterile water and placed in petri dishes of $15 \mathrm{~cm}$ diameter with three sheets of filter paper moistened with culture medium containing PCNB (SOUSA et al., 2008). The dishes were kept in incubation at temperature of $23{ }^{\circ} \mathrm{C} \pm 2{ }^{\circ} \mathrm{C}$ and a photoperiod of $12 \mathrm{~h}$ for seven days. After this period, the dishes were examined in a stereomicroscopy to observe pathogen growth on the fragments and in the culture medium, as well as purple pigmentation caused by the growth of the fungus in contact with the substrate containing PCNB.

IR percentage in the plants was obtained considering the number of pieces of mycelial growth in the number of plants per plot assessed. Furthermore, the TR of the seed to the plant, was determined based on the plant IR and the incidence of $F$. oxysporum $\mathrm{f}$. sp. vasinfectum recorded in inoculated seeds as: TR $(\%)=[\operatorname{IR}(\%) /$ IIS (\%) $] * 100$. Where, TR is the transmission rate of seed to plant; IR is the infection rate in the plant; IIS is the incidence of the pathogen in inoculated seeds.

To determine the IR in the produced seeds, samples of the harvested seed in the useful area of the parcels were analyzed. After removing the fiber, seeds were delinted with sulfuric acid, neutralized with calcium carbonate $2 \%$ and subjected to sterilization with sodium hypochlorite $2 \%$ for one minute. Then, the seeds were rinsed three times in distilled water, dried at temperature of $12 \mathrm{~h}$ and submitted to health analysis (NEERGAARD, 1979). Again, there was the addition of liquid semi-selective medium containing 
PCNB plus 2,4-D to the substrate (SOUSA et al., 2008). Disinfection was carried out in order to determine the percentage of seeds infected by the pathogen and to reduce contamination by saprophytic fungi. After seven days of incubation at temperatures of $23{ }^{\circ} \mathrm{C} \pm 2{ }^{\circ} \mathrm{C}$ and a photoperiod of $12 \mathrm{~h}$, the seeds were examined in the stereomicroscope.

IR percentage in the produced seeds was obtained considering the number of infected seeds according to the total number of evaluated seeds. The TR, plant to produced seed was determined based on IR in the seeds and the incidence of $F$. oxysporum $\mathrm{f}$. sp. vasinfectum the stems of analyzed plants: TR $(\%)=[\operatorname{IR}(\%) / \operatorname{IPS}(\%)] * 100$. Where, TR is the transmission rate of plant to seed; IR is the infection rate in seed produced; IPS is the incidence of the pathogen in plant stems.

\section{Statistical analysis}

Qualitative and quantitative data were submitted to variance analysis using SISVAR (FERREIRA, 2011). Averages between treatments, when significant by $F$ test, were compared by Tukey test $(P \leq 0.05)$ or were modeled with regression equations.

\section{RESULT}

Seeds of the FMT 701 and Delta Opal cultivars were considered moderately susceptible to Fusarium wilt in cotton, with initial profile of germination of $90 \%$ and $90.5 \%$ and $17 \%$ and $10.5 \%$ of incidence of Fusarium spp., respectively. Despite the moderately susceptibility, it was detected the presence of $F$. oxysporum f. sp. vasinfectum colonizing cottonseeds.

In evaluation of seed germination test, after inoculation, significant differences between cultivars and times of exposure were observed. Comparing the performance of cultivars, it was possible to observe the highest percentage of germination $(81 \%)$ for Delta Opal cultivar (Table 1).

Table 1. Seed germination (\%), Delta Opal and FMT 701 cultivars, inoculated with Fusarium oxysporum f. sp. vasinfectum.

\begin{tabular}{lc}
\hline Cultivar & Seed germination $(\boldsymbol{\%})^{*}$ \\
\hline Delta Opal & $81,0 \mathrm{a}$ \\
FMT 701 & $68,9 \mathrm{~b}$ \\
\hline CV $(\%)$ & $\mathbf{1 1 , 0}$ \\
\hline
\end{tabular}

* Means with same letter do not differ by Tukey test $(\mathrm{P} \leq 0.05)$.

In relation to germination, when compared the exposure time of seeds to the pathogen, it was observed that the percentage of normal seedlings was lower with increasing of the inoculum in seeds (Figure 1). As the percentage of occurrence of $F$. oxysporum f. sp. vasinfectum on seeds, there was a significant interaction between exposure time and cultivar. When analyzing to the cultivars on each time, there was a significant difference only at $24 \mathrm{~h}$ of seed exposure to the pathogen (Table 2). Pathogen occurrence was higher, reaching $100 \%$ of infection, with the increase of the seed inoculum. The maximum seed infection by the pathogen was estimated at 66h of exposure time in both cultivars (Figure 1). 
Figure 1. Seed germination (A) and incidence of Fusarium oxysporum f. sp. vasinfectum (B) on seeds, according to the seed exposure time to the pathogen.
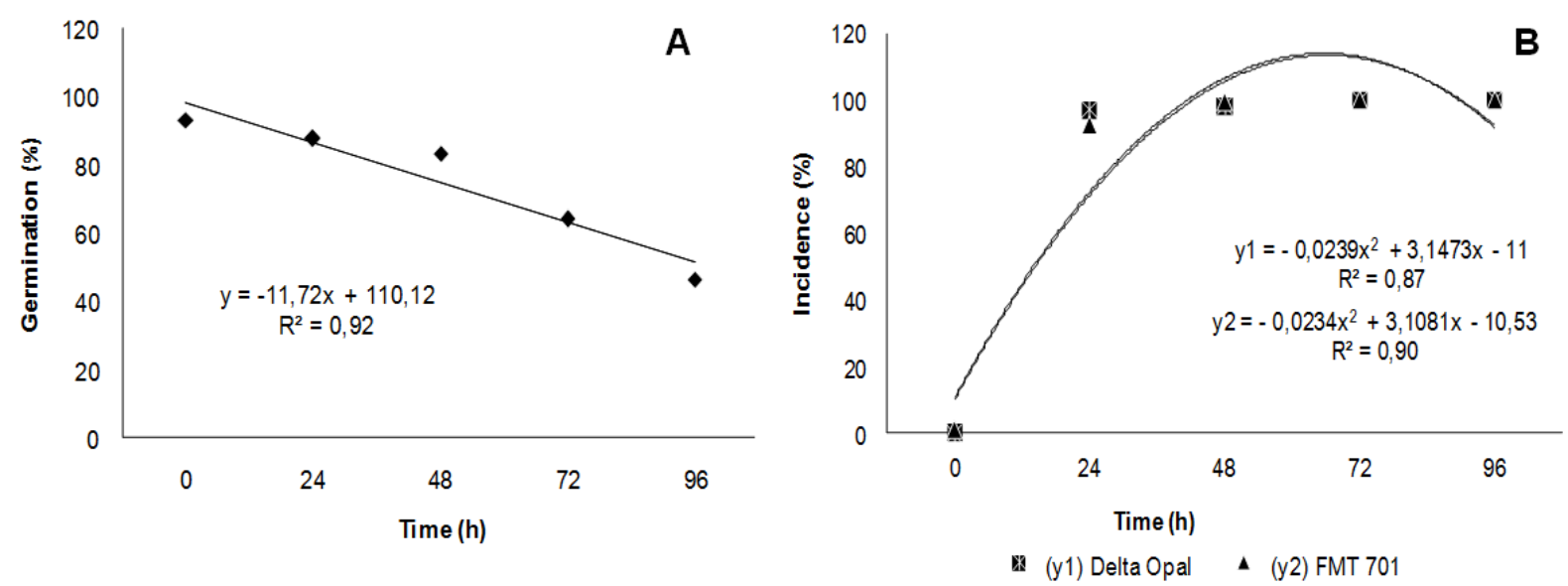

Analyzing to the initial stand, significant interaction was verified for exposure time and cultivar. In relation to the final stand and plant height, there was difference to exposure time and cultivar, without interaction. With the increase of exposure time, there was reduction of initial stand for both cultivars. This difference was significant at 96h, where Delta Opal cultivar had a better initial stand of plants (33.4\%) when compared to FMT 701 (7.4\%) (Table 2).

Table 2. Incidence of the pathogen on seeds and initial stand of seedlings of Delta Opal and FMT 701 cultivars inoculated with Fusarium oxysporum f. sp. vasinfectum at the different exposure time.

\begin{tabular}{|c|c|c|c|c|c|c|c|c|c|c|}
\hline \multirow[b]{2}{*}{ Cultivar } & \multicolumn{5}{|c|}{ Incidence } & \multicolumn{5}{|c|}{ Initial stand } \\
\hline & $\mathbf{O H}$ & $24 \mathrm{~h}$ & $48 \mathrm{~h}$ & $72 \mathrm{~h}$ & $96 \mathrm{~h}$ & $\mathbf{O h}$ & $24 \mathrm{~h}$ & $48 \mathrm{~h}$ & $72 \mathrm{~h}$ & $96 \mathrm{~h}$ \\
\hline Delta Opal & $0,25 \mathrm{a}$ & $97 \mathrm{a}$ & $98,5 \mathrm{a}$ & $100 \mathrm{a}$ & $100 \mathrm{a}$ & $65,2 \mathrm{a}$ & $49,0 \mathrm{a}$ & $42,8 \mathrm{a}$ & $40,2 \mathrm{a}$ & $33,4 \mathrm{a}$ \\
\hline FMT 701 & $1,12 \mathrm{a}$ & $92,5 \mathrm{~b}$ & $92,5 \mathrm{a}$ & $100 \mathrm{a}$ & $100 \mathrm{a}$ & $81,5 \mathrm{a}$ & $52,7 \mathrm{a}$ & $36,2 \mathrm{a}$ & $25,6 \mathrm{a}$ & $7,4 \mathrm{~b}$ \\
\hline CV (\%) & & & 2,7 & & & & & 27,7 & & \\
\hline
\end{tabular}

Means with same letter in column do not differ by Tukey test $(\mathrm{P} \leq 0.05)$.

Differences were evident for all evaluated exposure time, when there was a less marked reduction in the percentage of Delta Opal seedlings when compared to FMT 701 cultivar, with increasing exposure time of seeds to pathogen (Figure 2A). At analysis of final stand, there was better plant establishment to cultivar Delta Opal (83.3\%) 30 days after sowing (Table 3). However, the percentage of plants was lower with increasing of seed exposure time to the pathogen (Figure 2B). Higher plant height was observed in FMT 701 cultivar (85.0\%). It was found that results of plant height were also related to genetic characteristics, intrinsic to each cultivar. 
Figure 2. Initial stand among cultivars Delta Opal and FMT 701 (A), final stand (B), Incidence (C) and severity (D) of disease on stems of cotton plants, according to seed exposure time to Fusarium oxysporum f. sp. vasinfectum.
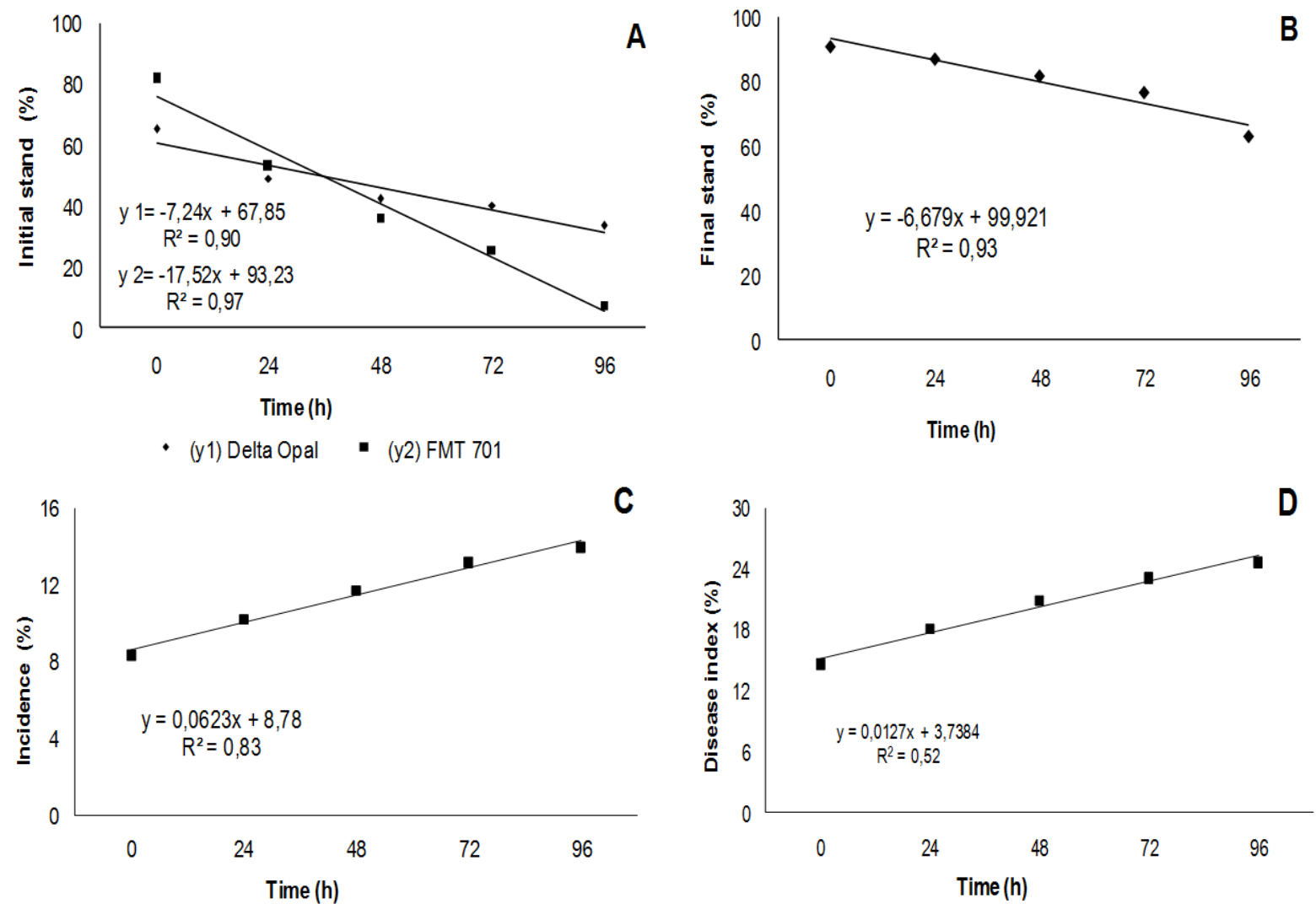

To Incidence and severity of disease, significant differences were observed between cultivars and between the seed exposure time to the pathogen. There were observed values between $9.4 \%$ and $14.1 \%$ of incidence and between $15.8 \%$ and $24.8 \%$ of severity on stems of Delta Opal and FMT 701 cultivars, respectively (Table 3).

Table 3. Final stand, plant height, incidence and severity of disease (DI) in plants of Delta Opal and FMT 701 cultivars derived from seeds inoculated with Fusarium oxysporum f. sp. vasinfectum.

\begin{tabular}{lcccc}
\hline Cultivar & Final stand (\%) & Plant height $(\mathbf{c m})$ & Incidence (\%) & DI (\%) $)^{\mathbf{1}}$ \\
\hline Delta Opal & $83,3 \mathrm{a}$ & $78,9 \mathrm{a}$ & $9,4 \mathrm{~b}$ & $15,8 \mathrm{~b}$ \\
FMT 701 & $76,5 \mathrm{~b}$ & $85,0 \mathrm{~b}$ & $14,1 \mathrm{a}$ & $24,8 \mathrm{a}$ \\
\hline CV $(\boldsymbol{\%})$ & $\mathbf{1 1 , 3}$ & $\mathbf{8 , 0}$ & $\mathbf{1 8 , 0}$ & $\mathbf{2 1 , 6}$ \\
\hline
\end{tabular}

Means with same letter in column do not differ by Tukey test $(\mathrm{P} \leq 0.05) .{ }^{1}$ Data were transformed to $\sqrt{x+1}$.

The effect of pathogen inoculum in the seeds, reflected in the incidence and severity disease presented in the plant stems, where Delta Opal cultivar had the lowest percentage of this two variables, when compared to FMT 701. Moreover, the incidence and severity disease were higher with increasing of seed exposure time to the pathogen (Figure 2C and 2D).

When assessing the infection (IR) and transmission (TR) rates, to the plant stems and to the produced seeds, there was significant difference only to the seed exposure time to the pathogen (Figure 3). 
The IR and TR were higher with increasing exposure time, reaching a maximum of $95 \%$ by around $73 \mathrm{~h}$ of seed exposure time to the pathogen, in both cases (Figures 3A and 3B).

Figure 3. Rates of infection (IR) (A) and transmission (TR) (B) of Fusarium oxysporum f. sp. vasinfectum on stems of cotton plants and rates of infection (IR) (C) and transmission (TR) (D) of Fusarium oxysporum $\mathrm{f}$. sp. vasinfectum to harvested seeds according to the seed exposure time to the pathogen. $\mathrm{C}$ and D data were transformed to $\sqrt{x+1}$.
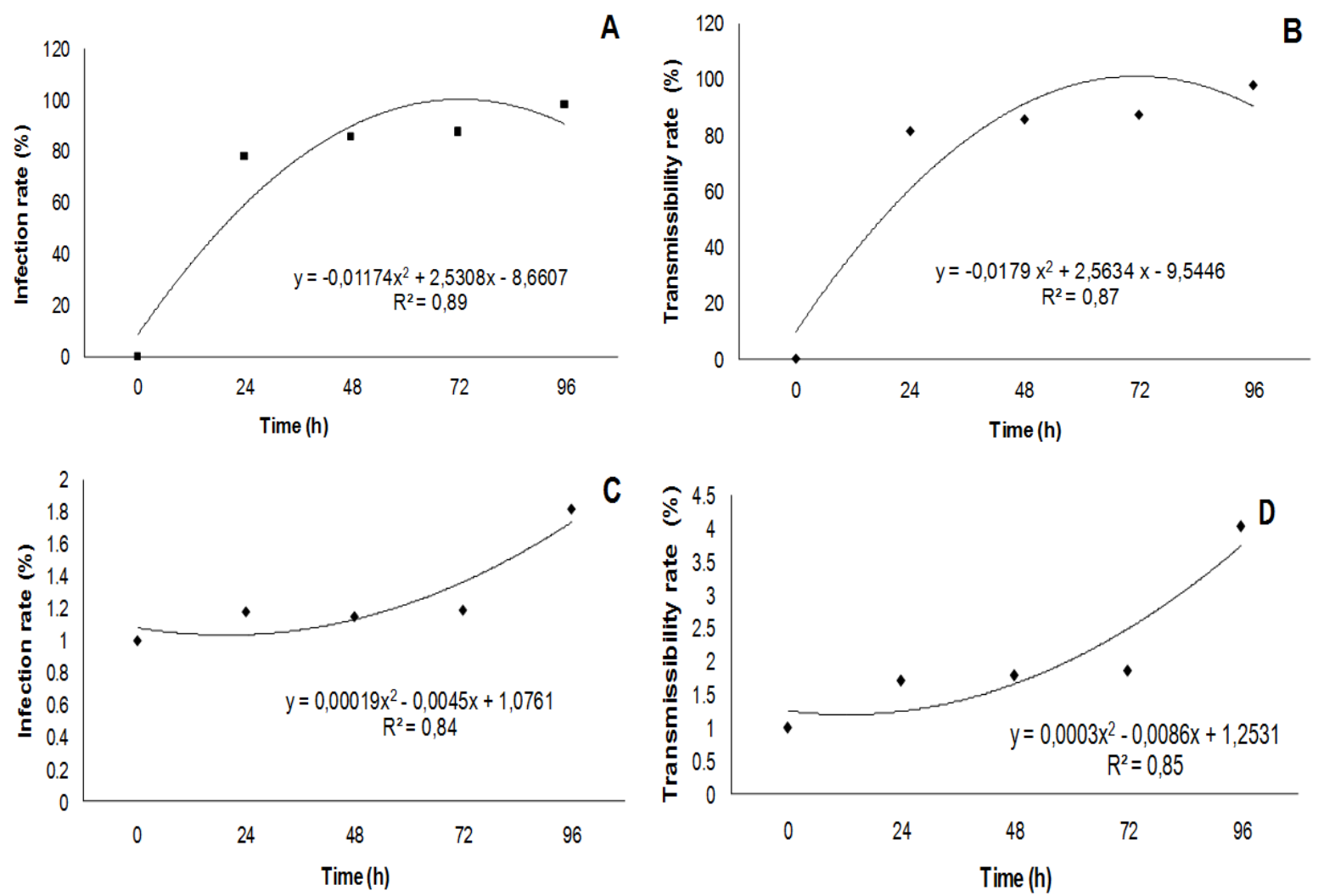

On the other hand, infection and transmission rates of the produced seeds, presented the highest values at the exposure time of $96 \mathrm{~h}$ and the minimum point of infection rate was around $20 \mathrm{~h}$ of exposure time. Similarly, there was the point of minimum transmission at $14 \mathrm{~h}$ of exposure time to the pathogen from seed, with a transmission rate around to $1.2 \%$ (Figures $3 \mathrm{C}$ and $3 \mathrm{D}$ ).

\section{DISCUSSION}

The inoculation of seeds was favorable to promote infection by the pathogen, with consequent effects on seed germination. The effect was greater with increasing of seed exposure time to the pathogen. These results confirmed literature information involving inoculation of cottonseeds with water restriction technique that observed a progressive percentage of germination reduction with increase of time of contact of the seed with the pathogen (MACHADO et al., 2004; TEIXEIRA et al., 2005; ARAÚJO et al., 2006; SOUSA et al., 2008; ARAÚJO, 2008).

The major occurrence of the pathogen in the inoculated seeds, confirmed the efficiency of the inoculation method used, increasing the inoculum in the seeds. Thus, it is appropriate to assume that this type of inoculation maybe related to the potential inoculum. Similar research of Araújo (2008) reported higher incidence of $F$. oxysporum f. sp. vasinfectum (90\% to $99 \%$ ) with increasing of inoculum, which was observed more markedly between the periods of $0 \mathrm{~h}$ and $72 \mathrm{~h}$ of seed exposure to the pathogen. Moreover, according to results of this study, the occurrence of the pathogen in the seeds as a function of 
exposure time, were consistent with those available in the literature for other pathosystems (TEIXEIRA; MACHADO, 2003; TEIXEIRA et al., 2005; ARAÚJO et al., 2006).

During the conduction and evaluation of the field experiment, average temperatures and rainfall varied around $25.6{ }^{\circ} \mathrm{C}$ and $122.5 \mathrm{~mm}$ (dates not shown), respectively. Infection by the pathogen and the occurrence of the disease were favored, however, the spread was little affected by the environment, considering the characteristics of monocyclic disease (CAMPBELL; MADDEN, 1990), as it is the case of cotton wilt. As the inoculum increased for both evaluated cultivars, seed germination and seedling emergence were significantly reduced, having an effect on initial and final stands. These results were consistent with those obtained by Sousa et al. (2008), which reported a decrease in the initial and final stands of cotton seedlings inoculated with $F$. oxysporum f. sp. vasinfectum. In another study about the influence of various pathogens inoculated in cottonseeds, among them $F$. oxysporum $\mathrm{f}$. sp. vasinfectum, the studied variables were negatively affected by the difference in water restriction and seed exposure time to the pathogens (MACHADO et al., 2004).

To Delta Opal cultivar, there was a gradual reduction in plant height, with increasing of exposure time. The same was observed for FMT 701 cultivar; however, the reduction in plant height was lower than that observed to Delta Opal cultivar. In a similar study, Araújo (2008) observed a gradual reduction in plant height with increasing exposure time of the cottonseeds to $F$. oxysporum f.sp. vasinfectum. Similarly, the height of corn plants inoculated with Acremonium strictum Gams was lower with increasing of seed exposure time to the pathogen at 0h, 24h, 72h and 120h (TEIXEIRA; MACHADO, 2003).

Sousa et al. (2008) observed in laboratory conditions, increase of the disease index when the seed exposure time to $F$. oxysporum f. sp. vasinfectum was increased from $24 \mathrm{~h}$ to $120 \mathrm{~h}$ by three methods of inoculation. Similarly, Teixeira et al. (1997) observed that the exposure time of $0 \mathrm{~h}, 15 \mathrm{~h}$ and $30 \mathrm{~h}$ influenced the disease index of cotton seedlings, grown from seeds inoculated with Colletotrichum gossypii South. The authors reported an increase of disease index for non-sterilized and sterilized cottonseeds after the inoculation. Furthermore, Araújo et al. (2006), evaluating the pathosystem $C$. gossypii South. var. cephalosporioides verified that the potential inoculum did not increased the incidence and severity of the disease of cotton seedlings at all evaluated times of exposure of $36 \mathrm{~h}, 72 \mathrm{~h}$ and $108 \mathrm{~h}$, however, the values were already high from the shortest period of seed exposure to the pathogen.

The results of infection and transmission rates found in stem fragments of cotton plants have been expressed values above those presented by Araújo (2008). According to this author, under controlled conditions, it has observed increased rates of infection and transmission from seed to seedling where the point of maximum infection and transmission of 50\% was observed at $78 \mathrm{~h}$ of contact of seeds with the pathogen. However, the results of infection and transmission rates obtained from the produced seed can be compared with studies using seeds from plants that presented wilt, with $9.9 \%$ and $47 \%$ of $F$. oxysporum f. sp. vasinfectum in production fields from India and Tanzania, respectively (KULKARNI, 1934; VEIGA, 1935; PERRY, 1962).

In Brazil, Veigas (1935) have noted the occurrence of the pathogen in only $0.6 \%$ of the analyzed seeds. Studies using DNA amplification of $F$. oxysporum f. sp. vasinfectum Race 4, in California, which was recovered from seeds harvested of plants grown in infected soil, and observed more clearly that pathogen can be transmitted effectively from plant to seed, with great potential to spread to other regions (BENNETT et al., 2008).

Following the same reasoning, Teixeira \& Machado (2003), working with maize seeds inoculated with A. strictum, observed that infection rate, as measured in the shoots of plants 28 days after sowing, was higher with increasing of the seed exposure time of $0 \mathrm{~h}$ to $120 \mathrm{~h}$. Furthermore, the transmission rate 
was similar at $24 \mathrm{~h}, 72 \mathrm{~h}$ and $120 \mathrm{~h}$, differing only at time $0 \mathrm{~h}$. Thus, it was observed that the infection of plant tissues may be directly related to the period of contact between seed and the pathogen.

\section{CONCLUSION}

The transmission of Fusarium oxysporum f. sp. vasinfectum, from cottonseeds is effectively and may reflect higher or lower infection and transmission rates, depending on the level of seed infection and the conditions inherent to the cultivars and the place where the culture is being installed.

\section{REFERENCES}

ARAÚJO, D.V. Caracterização molecular, patogenicidade e transmissão pela semente de Fusarium oxysporum f. sp. vasinfectum em algodoeiro. 2008. 102p. Tese (Doutorado) - Universidade Federal de Lavras.

ARAÚJO, D.V. et al. The influence of temperature and time of seed inoculation in the transmission of Colletotrichum gossypii var. cephalosporioides. Fitopatologia Brasileira, Brasília, v.31, n.1, p.35-40, 2006.

BRASIL. Regras para análise de sementes. Brasília: LANARV/SNAD/MA, 2009. 399p.

CAMPBELL, C.L.; MADDEN, L.V. Introduction to plant disease epidemiology. New York: Wiley, 1990. 532p.

CIA, E. et al. Performance of cotton genotypes in the state of São Paulo: yield, disease resistance and fiber quality. Ciência Rural, Santa Maria, v.38, n.2, p.326-331, 2008.

COLYER, P.D. Fusarium wilt. In: KIRKPATRICK, T.L.; ROTHROCK, C.S. (Eds.) Compedium of cotton diseases. Saint Paul: APS Press, 2001. 100p.

DAVIS, R.M.et al. Fusarium wilt of cotton: Diversity and implications for management. Plant Disease, v.90, n.6, p.629-703, 2006.

FERREIRA, D.F. Sisvar: a computer statistical analysis system. Ciência e Agrotecnologia, Lavras, v.35, n.6, p.1039-1042, 2011.

KULKARNI, G.S. Studies in the wilt disease of cotton in the Bombay Presidency. Indian Journal of Agricultural Science, v.4, n.6, p.976-1045, 1934.

MACHADO, A.Q.et al. Potential of water restriction use in cotton seed health testing. Fitopatologia Brasileira, Brasília, v.32, n.5, p.408-414, 2007.

MACHADO, J.C.; LANGERAK, C.J. Improvoment of a blotter method to detect economically important fungi associated with seeds of cotton. Ista Plant Disease Committee Symposium On Seed, v.1, p.48-58, 1993.

MACHADO, J.C.et al. Use of the water restriction technique in the inoculation of fungi in cotton seeds (Gossypium hirsutum). Revista Brasileira de Sementes, Pelotas, v.26, n.1, p.62-67, 2004.

MACHADO, L.P.et al. A simple and fast method to screen cotton genotypes for fusarium wilt resistance. Tropical Plant Pathology, Brasília, v.34, n.1, p.51-55, 2009. 
MCKINNEY, H.H. Influence of soil temperature and moisture on infection of wheat seedings by Helmintosporium sativum. Journal Agricultural Research, v.26, p.195-219, 1923.

MICHEL, B.E.; RADCFLIFFE, D. A computer program relating solute potential to solution composition for live solutes. Agronomy Journal, v.87, p.131-136, 1995.

NEERGAARD, P. Seed pathology. London: McMillan, 1979. 1025p.

NELSON, P.E.; TOUSSOUN, T.A.; COOK, R.F. Fusarium wilt of cotton: Fusarium: disease, biology and taxonomy. Pennsylvania: University Park and London, 1981. 474p.

PERRY, D.A. Fusarium wilt of cotton in the lake province of Tanganyika. Empire Cotton Growing Review, v.39, p.22-26, 1962.

SMITH, S.N.; SNYDER, W.C. Persistence of Fusarium oxysporum f. sp. vasinfectum in fields in the absence of cotton. Phytopathology, v.65, p.190-196, 1975.

SOUSA, M.V.et al. Methods of inoculation and effects of Fusarium oxysporum f. sp. vasinfectum in cotton seeds. Tropical Plant Pathology, Brasília, v.33, n.1, p.41-48, 2008.

SUASSUNA, N.D.; COUTINHO, W.M. Manejo das principais doenças do algodoeiro no cerrado brasileiro. In: FREIRE, E.C. (Ed.) Algodão no cerrado brasileiro. Brasília: ABRAPA, 2007. p.479-521.

TANAKA, M.A.S.; MENTEN, J.O.M. Comparison of methods for cotton seed inoculation with Colletotrichum gossypii var. cephalosporioides and C. gossypii. Summa Phytopathologica, v.17, n.3-4, p.218-226, 1991.

TANAKA, M.A.S.; MENTEN, J.O.M.; MARIANNO, M.I.A. Artificial inoculation of cotton seeds with Colletotrichum gossypii var. cephalosporioides and seed infection as a function of exposure time to the pathogen. Summa Phytopathologica, v.15, p.223-237, 1989.

TEIXEIRA, H.; MACHADO, J.C. Transmissibility and effect of Acremonium strictum in maize seeds. Ciência e Agrotecnologia, Lavras, v.27, n.5, p.1045-1052, 2003.

TEIXEIRA, H.; MACHADO, J.C.; VIEIRA, M.G. Influência de Colletotrichum gossypii South. No desenvolvimento inicial do algodão (Gossypum hirsutum L.) em função da localização do inóculo e desinfestação das sementes. Revista Brasileira de Sementes, v.19, p.9-13, 1997.

TEIXEIRA, H.et al. Water restriction technique: effect on Acremonium strictum, seeds protusion and obtaining of maize seeds infected. Fitopatologia Brasileira, Brasília, 30, n.2, p.109-114, 2005.

VEIGAS, A.P. A murcha do algodoeiro. Revista da Agricultura, v.10, p.49-51, 1935. 